\title{
THE DIFFICULTIES FACED BY INDONESIAN EFL LEARNERS IN PRONOUNCING "S" AND "ES" SUFFIXES IN THE SIMPLE PRESENT TENSE VERBS AND IN PLURAL FORM OF NOUNS
}

\author{
ANDRI SAPUTRA', M. ARIF RAHMAN HAKIM², EKO SAPUTRA³ \\ RAHMA $^{4}$ \\ Institut Agama Islam Negeri Bengkulu'2 \\ Lancaster University, United Kingdom ${ }^{3}$ \\ Victoria University of Wellington, New Zealand ${ }^{4}$ \\ andrisaputra@iainbengkulu.ac.id', arifelsiradj@iainbengkulu.ac.id², Ekosaputral7022019@gmail.com³, \\ rahmatyuri@myvuw.ac.nz ${ }^{4}$
}

DOI : http://dx.doi.org/10.29300/ling.v6i1.3004

Received: April 2020

Accepted: May 2020

Published: July 2020

\begin{abstract}
The authors perceive that Indonesian EFL learners find it challenging to pronounce $-s$ and -es suffixes properly. This position was first established during the authors' teaching experiences in some high schools, English centre course and colleges (for students majoring in English Education) in Indonesia. The observations were confirmed not only during teaching, but throughout the authors' own English study. It seemed difficult to adhere to the rules of suffix use in spoken language, i.e. How $-s$ and $-e s$ suffixes should and should not be pronounced during a conversation. Generally speaking, Indonesian EFL learners do not pay much attention to pronouncing the suffixes of $-s$ or $-e s$, and although many English users accept such mistakes in conversation with non-native speakers, it is not, however, an error a native-speaker is likely to make. In fact, this issue could lead to misunderstanding when non-native English users have conversations with native speakers. This study aims to present comparative literature review of a number research studies related to teachers' experiences and other EFL learners. Firstly, this study explains a presentation of existing relevant research on pronunciation is offered. This is followed by an explanation of the specific difficulties faced by Indonesian EFL learners in pronouncing $-s$ and $-e s$ suffixes in the present tense verbs and plural form of nouns. The discussion part suggests practical ways of dealing with the difficulties in pronouncing $-s$ and $-e s$ suffixes of present tense verbs and the plural form of nouns, and proposes several activities to this end.
\end{abstract}

Keywords: pronunciation, suffix, EFL learners

\section{INTRODUCTION}

\section{Introduction to Indonesian EFL Learners' Pronunciation}

In Indonesia, English is considered as a foreign language that is learnt in school, from the earliest level of education to university studies. Although English is commonly taught in schools, Indonesian people do not generally use it as a language of communication in society at large. Instead, Indonesian people employ various local languages in their homes or in informal situations. In formal situations - such as at school, work or during conferences Indonesian people generally use their national language to connect with their fellow citizens.

How to cite this article: Saputra, A., Hakim, M., Saputra, E., \& Rahmat, Y. (2020). The Difficulties Faced by Indonesian EFL Learners in Pronouncing "S" and "Es" Suffixes in the Simple Present Tense Verbs and in Plural Form of Nouns. Linguists : Journal Of Linguistics and Language Teaching, 6(1), 55-65.

doi:http://dx.doi.org/10.29300/ling.v6i1.3004 
It is commonly understood that learning English is perceived as difficult for most Indonesian EFL learners. One of the reasons for this is that for Indonesian people, English is distinctive not only in its vocabulary but also in its pronunciation, tenses, grammar, syntax, and meaning (Sholihah, 2014). Besides this, based on the author's experience learning and teaching English, pronunciation is one of the most challenging aspects of EFL instruction. It may be assumed that this issue is due to the marked difference between L1 and L2. This is a wellobserved phenomenon; Papachristou (2001: 1), for instance, notes that "the account of this initial mapping of the perceptual space into categories, learning / mastery of a second language is difficult to attain, particularly, with reference to phonetic contrasts"

Additionally, owing to the various dialects as well as local accents which Indonesian people have, English pronunciation is considered hard to master, particularly the $-s$ and $-e s$ suffixes found at the end of verbs in the simple present tense and plural form of a noun. It is commonly acknowledged that mispronouncing English words is to be avoided when speaking English as it could lead to confusion. Azzar (2013) shows in her Fundamental Grammar Book that when the -es suffix is joined to words that end in $-s h,-c h,-x,-s$, and $-z$, then the -es suffix is pronounced $/ \partial z /$, for example, the main verb in the following sentence: He washes the car on Sunday mornings. The $-s$ suffix, however, is joined to most verbs and can be pronounced both /s/ and /z/.

The other difficulty in pronouncing $-s$ and $-e s$ suffixes occurs when Indonesian EFL learners have to change the noun form from singular to plural. For example, a car becomes two cars. Based on Essential Grammar in Use, by Murphy (2007), the plural form of a noun must have the suffix-es if the singular word ends in $-s,-c h,-s h$, or $-x$, and in this case it is pronounced $/ \partial z /$. Moreover, if the noun ends in-y- for instance, baby- the -yis changed into -ies, and is pronounced /z/.Thus, baby becomes babies, and is pronounced [beIbi:z]. However, not all nouns that end with $-y$ are automatically transformed into -ies. If the noun ends with a- $y$ which is preceded by a vowel sound (for example, day-days, monkey - monkeys) the ending remains $-y s$ and the $-s$ suffix is pronounced /z/. Moreover, if the noun ends with $-f e$ or $-f$ this will to be changed to $-v e s$, the $-s$ being pronounced /z/.

Interestingly, the -es suffix is consistently pronounced / Әz/ whereas the $-s$ suffix can sound like either $/ \mathrm{s} /$ or $/ \mathrm{z} /$, depending on the preceding phoneme. Take stars as a typical example. The $-s$ suffix on the word stars is pronounced $/ \mathrm{z} /$, because there is a voiced sound (i.e. $d, r, l, m, b$ sounds and all vowel sounds) before the-s suffix. However, the- $s$ suffix is pronounced /s/ if the singular noun ends in a voiceless phoneme $(k, t, p)$ such as in seats (Azzar, 2003). 


\section{LITERATURE REVIEW}

\section{Previous Research on Pronunciation}

It has been expounded that pronunciation is one of the important aspects in the English learning process, as errors here could lead to misunderstandings among English users. Gilakjani (2011), for instance, suggests that pronunciation is one of the essential components of English, and can prove an obstacle for EFL learners when learning English. Fraser (2000, cited in Gilakjani, 2011) adds that pronunciation is a key feature of EFL, and disregarding it can lead to difficulties in communication. Moreover, there is a general concurrence that it is necessary for language teachers to assist EFL learners in pronouncing English phonemes well to avert misunderstandings and frustration (Hamer, 1991). Thus, practical instruction in pronunciation has been established as a cornerstone of EFL learning and teaching.

If it has been ascertained that pronunciation is a vital element of language teaching, it follows that the approach adopted to teach pronunciation should also be discussed. Teachers are currently advised to provide direct instruction when teaching English pronunciation in order to confer maximum benefit. Numerous studies have revealed the effectiveness of explicit instruction in increasing attention and awareness in second language classrooms (see Norris \& Ortega, 2000; Spada \& Tomita, 2010). Dekeyser (2008) and Ellis (2009) posit that explicit instruction can act as a trigger for learners to advance their meta-linguistic awareness of regulation in English, which can be gained deductively by showing learners an illustration of the regulation in question, or inductively by assisting in deducing the regulation from data. Therefore, EFL learners need to be taught English pronunciation directly and explicitly, thereby effectively developing their awareness of language.

Some researchers have conducted studies on the errors most frequently made by Indonesian EFL learners in English pronunciation, and most of these studies show that Indonesian learners have difficulty in pronouncing final consonants. Mathew (1997), for instance, revealed that most voiceless final stops were unreleased (for complete study results, see Error in Pronunciation of Consonants by Indonesian, Gayo and Acehnese learners of English as Foreign Language).

Another pronunciation error frequently made by Indonesian EFL learners regards the pronunciation of $-s$ and -es suffixes. Khairy's study ("Pronunciation Errors of Plural Sound (S/ES) at Students at one the Universities of Surabaya, Indonesia", 2015) reported that the learners in question pronounced the /s/ sound properly one hundred percent of the time and the /z/ sound properly ninety-five percent of the time. However, they pronounced the /oz/ sound incorrectly for one hundred per cent of the time. The result of the study illustrated that these learners could pronounce words with a voiceless non-sibilant segment well, e.g. things, students, groups and persons. On the other hand, EFL learners had difficulties in pronouncing Linguists: Journal of Linguistics and Language Teaching Vol. 6, No. 1, July 2020 

words with voiced non-sibilant segment, such as questions, values, and names. Besides this, the learners also mispronounced words with a sibilant segment, such as sentences, paraphrases and places. These findings concerning Indonesian learners in particular correlate with those of Mathew (1997), when taken in the context of general English pronunciation.

As illustrated in figure 1, the consonant $-\mathrm{s}$ and -es suffixes are on the same line in the English pronunciation table.

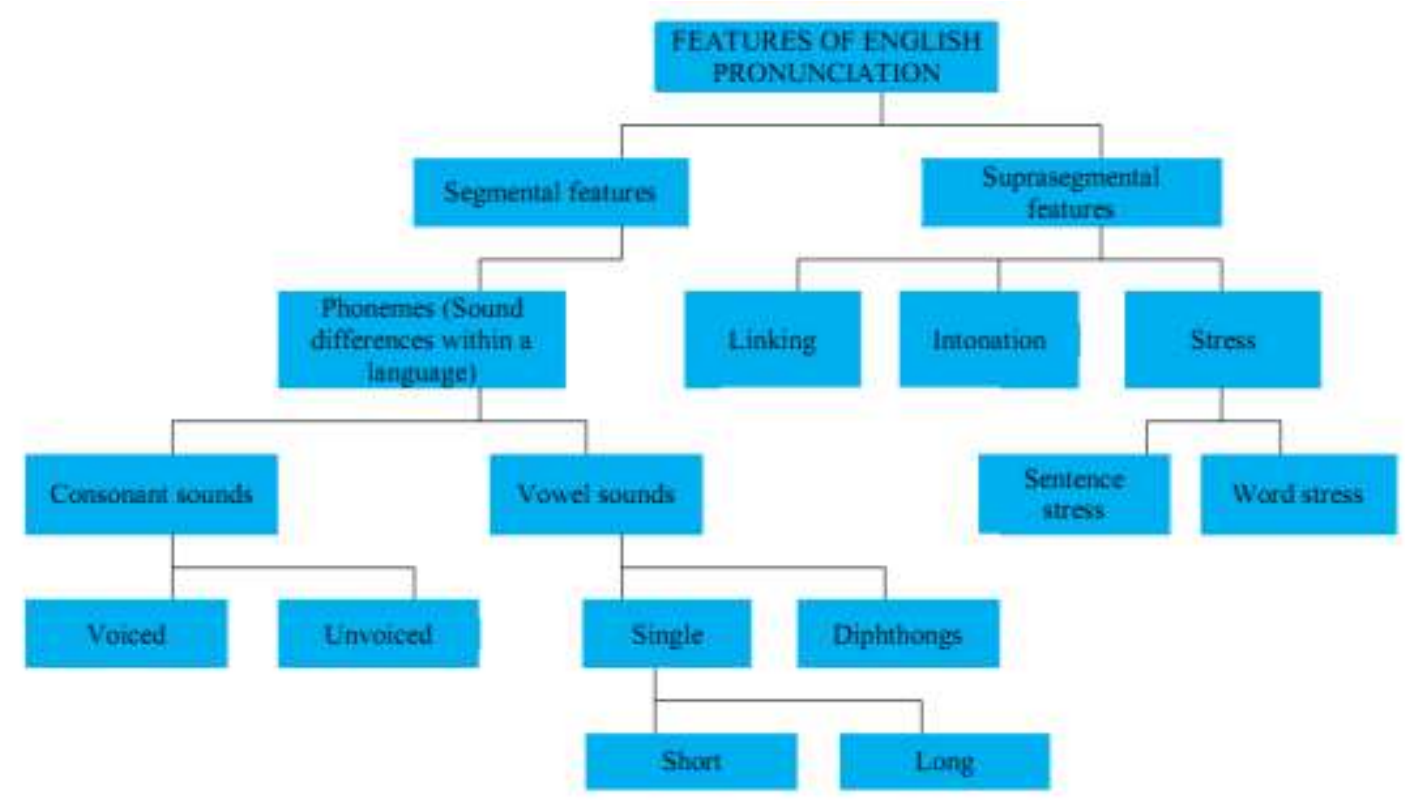

Figure 1: Features of English Pronunciation (Gilakjani, 2012)

Consonants and $-s$ and $-e s$ suffixes (i.e. the 'Voiced' non-sibilant segment and sibilant segment) are on the same line under 'Segmental features'. Florez in Chiu (2016) suggests that segmental features are considered as primary sounds in the way they cooperate to create spoken language. Conversely, many scholars (Hall, 1997; Florez, 1998;Wong, 1993, cited in Chiu) argue that supra-segments such as stress, tone, rhythm and intonation are more important in spoken English than segmental features. It could be contended, however, that the ability to pronounce the smallest sound (such $-s$ and -es suffixes) is a crucial one when learning English, as neglecting the pronunciation of $-s$ and -es suffixes in the present tense verbs and the plural form of nouns could lead to misalignment or incompatibility with standard English grammar. This argument would support the importance of segmental features as an area of focus for learners and teachers.

As well as being primary sounds in English, at $-s$ and -es also act in phonology as sorts of morphemes. Morphemes are defined by Yale (2010) as the smallest part of a word that has grammatical function and meaning. It has a range of methods of pronunciation depending on a word's final sound. The various possible pronunciations of sounds are known as allomorphs (with the possible sounds of $-s$ and $-e s$ being/s/,/z/, and /oz/, McCarthy-Carstrairs,2002). 
Similarly, the rules of how to pronounce the $-s$ and -es suffixes of present tense verbs depend on the final phoneme which precedes the allomorphs. According to Fromkin et al. (2011), the final segment of singular noun forms and the third-person singular verb forms shape the allomorphs plural formation in English. These pronunciation rules are briefly outlined in the tables 1 and 2 as follows:

Table 1:(Frankin et al. (2011)

\begin{tabular}{|c|c|c|c|}
\hline \multirow[t]{2}{*}{ Nouns } & $\begin{array}{l}\text { Voiced Non-sibilant } \\
\text { Segments /z/ }\end{array}$ & $\begin{array}{l}\text { Non-sibilant } \\
\text { Segments /s/ }\end{array}$ & $\begin{array}{c}\text { Sibilant Segment } \\
/ \partial z /\end{array}$ \\
\hline & 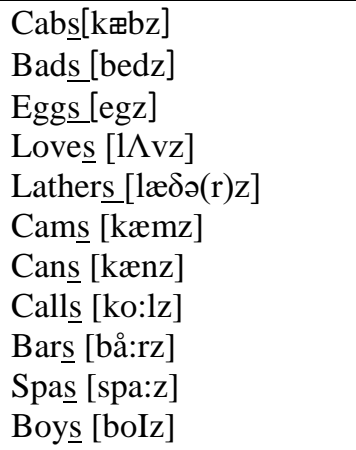 & $\begin{array}{l}\text { Caps [cæps] } \\
\text { Cats [kæts] } \\
\text { Backs [bæks] } \\
\text { Caffs [kæts] } \\
\text { Faiths [feIøs] }\end{array}$ & 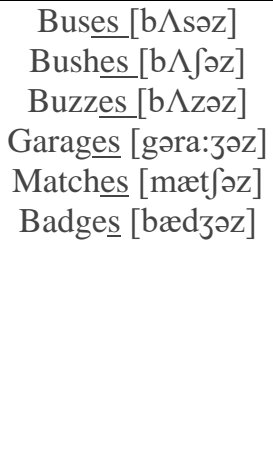 \\
\hline
\end{tabular}

Table 2: Frankin et al. (2011)

\begin{tabular}{|c|c|}
\hline Allomorph & Environment \\
\hline $\mid \mathrm{z} /$ & After [b], [d], [g], [v], [ð], [m], [n], [y], [1], [r], [a:], [эг] \\
\hline$/ \mathrm{s} /$ & 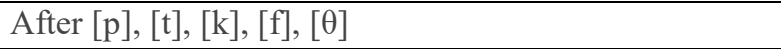 \\
\hline /əz/ & after $[\mathrm{s}],\left[\int\right],[\mathrm{z}],[3],\left[\mathrm{t} \int\right],[\mathrm{d} 3]$ \\
\hline
\end{tabular}

According to Frankin et al. (2011), the rules of the pronunciation of the $-s$ and $-e s$ suffixes in the plural form of nouns is the same as in the present simple tense of verbs, or the third-person singular form. Thus, correctly understanding and pronouncing $-s$ and $-e s$ is a key concept which allows students to better understand multiple aspects of English structures, andultimately-meaning.

\section{Difficulties in Pronouncing $-s$ and -es Suffixes}

Mispronouncing English words is still one of the major English learning issues for Indonesian students. This may well be attributed to the interference of the Indonesian native language systems with the target language. These native language systems may contribute to the failure to communicate fluently using English. Brown (2000) suggests that the primary obstacle to second language acquisition is the intrusion of the L1 system into the developing L2 system. Furthermore, Stokel (2003) asserts that as learners are likely to transfer the habits of their native language structure to the target language, so this becomes a major barrier in mastering the structure of a target language. It would seem logical to assume that sharing similar structures in the native and target language would effectively facilitate learner's understanding and proficiency. It follows that, where the first and target language share fewer Linguists: Journal of Linguistics and Language Teaching Vol. 6, No. 1, July 2020 
common features, students would be at a disadvantage in terms of the relative speed and ease of their progress. A comparison of English and Indonesian would likely reveal that they fall into the latter category.

There would appear to be many constraints for Indonesian students in learning English, not least of all those regarding pronunciation between the two languages. The first difficulty confronted by the learners is that they have distinct phonological systems between Bahasa Indonesia (Indonesian Language) and English. This is based on the previous research conducted by Riani and Prayogo (2012). They found 506 pronunciation errors out of the 2,569 words made by Indonesian singers in singing English songs. Surprisingly, they found that errors in pronouncing consonant phonemes accounted for the highest percentage of errors overall (44.66\%). The Indonesian language does not have some sounds which English does, such as the plosive labials /p/, and /b/. The Indonesian language has these sounds, but they are not plosive. Similarly, the Indonesian language, unlike English, does not have coronal sounds like $/ \theta /, / \partial, / \mathrm{J} / / 3 /, / \mathrm{t} \int$, and $/ \mathrm{d} z /$. The impact of this can clearly be seen when focusing on the pronunciation of $-s$ and -es suffixes in the simple present tense verbs and plural nouns. Besides this, Indonesian does not have a system in which the singular form is changed to a plural one, as well as adding the /s/ sound, or in the verbs. Such rules frequently confuse students. For example, to say two bags, Indonesian speakers can simply say dua tas (two bags) without adding a final morpheme or more phonemes. So, these differences become a prominent obstacle for Indonesian EFL learners to speak fluently, as initially they must take time to consider the correct sound they produce, thereby ensuring nouns match their number.

Another difficulty is that the students' knowledge of rules of English phonology is often limited. Evidence of this is presented by Fatimah (2010), who conducted interviews with firstgrade students of senior high school (16 o 17 years old) claiming that they did not know general information about the rules of English phonology. Undoubtedly, in second language instruction, an understanding of basic rules of will help students better grasp the underlying systems of pronunciation. It is also in line with the author's experience where he learned English for the first time. During the time, he did not know phonological rules of English, so that learning English pronunciation seemed difficult. Therefore, the author perceives that phonological awareness is helpful to know how Standard English words are pronounced.

\section{METHOD}

This study employs a qualitative approach in which the authors uses literature review design. In other words, data gained is from a number of published literature (Green, Johnson \& Adams, 2006). Moreover, the researchers analyse some related cases such as cases occur in 
Indonesia and researchers' own experiences. Also, it is important to underline that this study does not aim to display negative criticism or weaknesses om literature review only, but it aims to present similarities and differences.

\section{FINDINGS AND DISCUSSION}

\section{Ways of Dealing with the Difficulties}

Many approaches and methods can be applied to help Indonesian EFL learners overcome the difficulties faced in pronouncing $-s$ and -es in the present tense verbs and plural form of nouns. One of them is the use of Audio-Visual Aids (AVAs). AVAs are teaching aids which use media other than speech in the learning process (Pool, 1998). Elliot et al. (1998), state that regularly presenting material in different formats - for instance, visual and auditory can supplement teacher-or text-based presentations. Moore (1999: 162) suggests that:

"Classroom audiovisual equipment today is lighter, more energy efficient, and easier to operate than in the past. Video and television are similar in that they both portray moving images, along with sounds, and in that these sounds may be either natural or contrived and tailored to desired situation. Additionally, as instructional tools, both providing a teacher the opportunities for presenting, describing, and clarifying information, ideas, and concepts; for teaching a skill; for condensing or expanding time; and for affecting attitudes."

Additionally, the utilization of AVAs can make learning pronunciation more interesting, since students can more readily visualize what is being said. Gower et al. (1995) argue that video makes meaning much easier to grasp as it incorporates the speakers' expressions and body movements. To sum up, AVAs are an effective method to teach pronunciation to students, because they offer students the opportunity to listen to the information as well as see the visual component that facilitates a fuller understanding of the information.

Another effective method of instruction is the use of minimal pairs. Avery and Ehrlich (1995) stated that minimal pairs are pairs of words which have a distinct meaning based on the basic alteration of only one sound. In other words, a minimal pair involves a couple of words pronounced similarly, except for a single phonemic distinction. A phoneme is minimum unit of significantly specific sound, and just one phonemic distinction can be responsible for entire alterations in word meaning, as in the case of the minimal pairs think-thing, and seat-sit. As a result, error in pronouncing these sounds could lead to misinterpretations of the word, phrase or sentence meaning (Nilsen and Nilsen, 1973).

Minimal pairs have relevancewhen dealing with the difficulty faced by Indonesian EFL learners in pronouncing -sand -es suffixes in the present tense verbs and plural form of nouns. This is because when learners try to compare and contrast the differing sounds through study Linguists: Journal of Linguistics and Language Teaching Vol. 6, No. 1, July 2020 

of minimal pairs, the prominence of these differing sounds in designating word meaning is naturally moved to the forefront of the learners' mind. Rajadurai (2001) suggests that pronunciation class makes students more sensible of their own pronunciation, and aware of how this pronunciation is distinct from the model offered. In the context of pronouncing $-s$ and -es suffixes in the simple present tense verbs and plural form of nouns, students can be encouraged to start with the differing sound /s/ and /z/ in the two words bats and beds. The word bats is pronounced [bæts] with an-s suffix sound while bed is pronounced [bedz] with s sound /z/. Thus, this activity may help students tackle on aspect of their difficulties (i.e. pronouncing $-s$ and -es suffixes in the present tense verbs and plural form of nouns).

\subsection{Activities}

\section{Activity 1}

Using Audio Visual Aids to practice pronouncing $-s$ and -es suffixes in the simple present tense verbs and plural forms of nouns can be effective, based on the author's experience. One example of the media that can be used as an audio-visual aid is the Google translate online dictionary (a detailed description of how the following activity can be applied is found in the lesson plan in the appendix). With this dictionary, students can listen to the standard pronunciation of English to differentiate the suffix sounds, a feature which can be used as a teaching aid in the classroom. For instance, the teacher can give a list of words on the board (see Table 3).

Table 4: Author's own

\begin{tabular}{|l|l|c|c|c|}
\hline \multicolumn{2}{|c|}{ Nouns } & \multicolumn{2}{c|}{ Verbs } \\
\hline Cabs & Caps & Buses & Watches & Cooks \\
Bads & Cats & Bushes & Washes & Hits \\
Eggs & Backs & Buzzes & Fixes & Jumps \\
Loves & Caffs & Garages & Goes & Writes \\
Lathers & Faiths & Matches & Misses & Types \\
Cams & & Badges & & \\
Cans & & & & \\
Calls & & & & \\
Bars & & & & \\
Spas & & & & \\
Boys & & & & \\
\hline
\end{tabular}

The teacher shows the list of words on the board through in-focus in the classroom, and then opens the Google translate online dictionary. Afterwards, the teacher asks the students to listen to the audio provided by the dictionary, and encourages students to repeat the word. The teacher can also divide students into groups or pairs to practice with their peers. Pair work is generally considered helpful as students tend to correct their pronunciation together. 


\section{Activity 2}

Another practical technique to deal with the issue in question is that of using minimal pairs. One activity used by the author (please see the appendix for a detailed description) starts by asking students to work in pairs. The teacher then gives a handout containing list of minimal pairs.

\begin{tabular}{|l|}
\hline For example: \\
beds and bats. \\
goods and goats \\
loves and loops \\
watches and washes \\
\hline
\end{tabular}

This kind of activity is particularly helpful for students wishing to practice not only the pronunciation of $/ \mathrm{s} /, / \mathrm{z} /$ and $/ \mathrm{\partial z} /$ sounds but also the identification of the different sounds of the words they hear. This approach is in line with theory which says that once students are aware of identifying the different sounds of the words, they can then effectively improve their own pronunciation (Rajadurai, 2001).

\section{CONCLUSION}

Indonesian EFL learners routinely find difficulties in learning English, especially concerning English pronunciation. It cannot be denied that English pronunciation is difficult for some learners. In this paper, the author reviews the difficulties faced by Indonesian learners in pronouncing $-s$ and -es suffixes in the present tense of verbs and plural form of nouns. It is suggested that Indonesian EFL learners find difficult these suffixes because of the influence of the mother tongue, the difference between the Indonesia and English phonological systems, and a lack of knowledge regarding English phonological rules.

To counter these difficulties, the author offers two methods and activities which have proved helpful for students wishing to tackle this problem. These methods comprise the use of audio visual aids and minimal pairs. The two approaches were used by the author to teach English pronunciation, who found them particularly useful in improving the students' pronunciation. They provide a promising basis on which to develop further pronunciation teaching methods, which may prove even more effective and interactive. Furthermore, although the methods outlined were felt to be beneficial, further study and practice is needed to ensure that they can adapted for use in all schools, regardless of the facilities available.

\section{REFERENCES}

Avery, P., and Ehrlich, S. (1995). Teaching American English Pronunciation. Oxford: Oxford University Press.

Azzar. B. S. (2003). Fundamentals of English Grammar. Boston: Longman. 
Brown, D. (2000). Principles of Language Learning and Teaching (4th Ed.). London:

Longman.

Chiu, H, W. (2016). Teaching Components: Supra Segmentals or Segmentals.[ONLNE]

Available at http://www.52englishzone.com/2016/03/teaching-componentssuprasegmentals-or.html. [Accessed 3 Desember 2016]

Dekeyser, R. (2008). Implicit and explicit learning. In C. J. Doughty \& M. H. Long (Eds.), The handbook of second language acquisition (pp. 313- 348). Malden, MA: Blackwell.

Ellis, R. (2009). Implicit and explicit learning, knowledge and instruction. In R. Ellis, S. Loewen, C. Elder, R. Erlam, J. Philip, \& H. Reinders (Eds.), Implicit and explicit knowledge in second language learning, testing and teaching (pp. 3-25). Bristol, UK: Multilingual Matters.

Elliot, Stephen N., Thomas R. Kratochwill, Joan Littlefield, John F. Travers. 1998. Educational Pshycology: Effective teaching, Effective Learning. Second Edition. Boston: Mc.GrawHill International.

Fromkin, V., Rodman, R., \& Hyams, N. (2011). An Introduction to Language. Canada: Cengage Learning.

Hanner, J. (1991). The practice of English Language Teaching. London: Longman.

Hinofotis, F., \& Bailey, K. (1980). American undergraduates' reactions to the communication skills of foreign teaching assistants. On TESOL, 80, 120-133.

Khairy. A. (2015). Pronunciation Errors of Plural Nouns (S/ES) by Kemenag Class Students at the State University of Surabaya Academic Year 2015.[ONLINE] Available at http://www.geges-ndl.com/2016/03/pronunciation-errors-of-plural-sound-s.html. [Accessed 30 Novemver 2016].

Gilakjani, A. P. (2011). A Study on the Situation of Pronunciation Instruction in ESL/EFL Classrooms. Journal of Studies in Education, 1(1), 1-15. Doi:10.5296/jse.v1i1.924

Gower, Roger, Diane Phillips, and Steve Walters. 1995. Teaching Practice Handbook. Oxford: Heinemann.

Green, B. N., Johnson, C. D., \& Adams, A. (2006). Writing narrative literature reviews for peer-reviewed journals: secrets of the trade. Journal of chiropractic medicine, 5(3), 101-117.

Papachristou, V. (2011). Explicit vs. Implicit Pronunciation Teaching to Greek children: the case of the acquisition of English vowels. .[ONLINE] Available at http://www.enl.auth.gr/symposium19/19thpapers/035_Papachristou.pdf. [Accessed 30 Novemver 2016].

Poole, Bernard J. 1998. Education for an Information Age Teaching in the Computerized 
Classroom. Second Edition. Boston: Mc.Graw-Hill College.

Mathew, I. B. D. (1997). Errors in Pronunciation Of Consonants by Indonesian, Gayo and Acehnese Learners of English as A Foreign Language. (Master of Arts), Edith Cowan University.

Moore, Kenneth D.1999. Middle and Secondary School Instructional Methods. Second Edition. Boston: Mc.Graw-Hill College.

Nilsen, D.L.F., and Nilsen, A.P. (1973). Pronunciation Contrasts in English. New York: Regents Publishing Company, Inc.

Carstairs-McCarthy, A. (2002). An Introduction of Morphology: Words and Their Structure. Edinburgh: Edinburgh University Press.

Norris, J. M., \& Ortega, L. (2000). Effectiveness of L2 instruction: A research synthesis and quantitative meta-analysis. Language Learning, 50, 417-528.

Sholihah, U. (2014). The Differences between English and Indonesian Language. Available at http://download.portalgaruda.org/article.php?article=253168\&val=6820\&title=THE\%20DIFF ERENCES\%20BETWEEN\%20ENGLISH\%20AND\%20INDONESIAN\%20LANGUAGE [16 December 2016].

Spada, N., \& Tomita, Y. (2010). Interactions between type of instruction and type of language feature: A meta-analysis. Language Learning, 60, 263-308.

Storkel, H. L. (2003). Learning New Words II Phonotactic Probability in Verb Learning. Journal of Speech, Language, and Hearing Research, 46(6), 1312-1323.

Rajadurai, J. (2001). An investigation of the effectiveness of teaching pronunciation to Malaysian TESL students. Forum, Vol 39 No 3, July - September. Retrieved on 14 October, 2004, from http://exchanges.state.gov/forum/vols/vol39/no3/p10.htm

Riani, I, O \& Prayogo, A .(2012). An Analysis of Pronunciation Errors Made by Indonesian Singers. Malang: State University Malang.

Yule, G. (2010). The Study of Language ( $4^{\text {th }}$ ed.). New York: Cambridge University Press. 